\title{
Characterization of Ralstonia solanacearum Causing Bacterial Wilt Disease of Tomato in Coimbatore District of Tamil Nadu, India
}

\author{
A. Balamurugan ${ }^{1}$, M. Muthamilan ${ }^{1 *}$, A. Kamalakannan ${ }^{1}$,
} A. Shanthi ${ }^{2}$ and T. Arumugam ${ }^{3}$

\author{
${ }^{1}$ Department of Plant Pathology, ${ }^{2}$ Department of Nematology, ${ }^{3}$ Department of Vegetable \\ Crops, Tamil Nadu Agricultural University, Coimbatore - 641003, Tamil Nadu, India \\ *Corresponding author
}

A B S T R A C T

\section{Ke y w ord s \\ R. solanacearum, Characterization, Biolog finger printing \\ Article Info \\ Accepted: \\ 20 January 2020 \\ Available Online: \\ 10 February 2020}

Ralstonia solanacearum isolates collected from wilt affected tomato plants in Coimbatore district of Tamil Nadu were characterized by morphological, biochemical and race analysis. The isolates produced typical irregular, whitish fluidal single colonies along with pinkish center on $1 \%$ TZC amended CPG agar media. Pathogenicity test revealed the representative isolates could wilt the tomato seedlings, and tobacco leaf infiltration assay confirmed its race 1 nature. Biochemical assays revealed the isolates belong to biovar 3 and species level identity was confirmed as $R$. solanacearum through Biolog finger printing assay.

\section{Introduction}

Tomato (Solanum lycopersicum L.) is the most important solanaceous vegetable crop being cultivated all over the world and also responsible for red revolution in India. The tomato fruit are an important part of a healthy diet, because they help to lower blood pressure, heart disease, prevents some type of cancer and positive effect upon blood sugar (Rocha et al., 2013). Several biotic and abiotic factors limiting the cultivation of tomato, but the bacterial wilt disease caused by Ralstonia solanacearum (Smith, 1896) Yabuuchi et al. (1995) is one of the most devastating disease cause deadly effects in tomato. The yield loss in India due to tomato bacterial wilt disease was estimated 10 to $90 \%$ (Ram et al., 2013). Based on scientific and economic importance $R$. solanacearum is ranked as second among top ten most important bacterial plant pathogens all over the world (Mansfield et al., 2012).

The pathogen $R$. solanacearum is a gramnegative, aerobic, soil-borne bacterium which belongs to $\beta$-subdivision of the Proteobacteria. Traditionally, $R$. solanacearum classified into five races based on its host specificity (Buddenhagen and Kelman, 1964), five 
biovars based on utilization of different carbohydrate media (Hayward, 1964) and four phylotypes based on its geographic origins (Fegan and Prior, 2005). R. solanacearum is widely distributed in tropical, sub-tropical and certain warm temperate countries of the world which causes vascular wilt in a wide range of hosts over 450 plant species and more than 50 families (Garcia et al., 2019). In this current study we characterize the $R$. solanacearum isolates infecting tomato from the Coimbatore district of Tamil Nadu, India for its pathogenicity, race and biovar nature respectively.

\section{Materials and Methods}

\section{Isolation, pathogenicity assay and race identification of $\boldsymbol{R}$. solanacearum}

Recently, severe bacterial wilt disease was found to be recorded in tomato fields from two location viz., Kinathukadavu and Othakalmandapam of Coimbatore district, Tamil Nadu during 2017 cropping season. A comprehensive diagnosis of disease symptoms was done with wilt affected tomato plants and their symptomatology was recorded. To know the disease etiology the 'ooze-out or streaming test' was performed using these affected plants at on spot field conditions. These wilt affected tomato plants were collected separately from two locations and brought into lab. Pathogen isolation was performed on Kelman medium according to Kumar (2006) and Sakthivel et al. (2016) as follows; the infected stems were washed under running tap water to remove adherents followed by surface disinfectant with $0.1 \%$ mercuric chloride for 30 seconds. Then the stems were thoroughly washed three times using sterile distilled water (SDW) and blot dried. Stems were then cut into small pieces $(1 \mathrm{~cm})$ and allowed to soaking in a vial containing $5 \mathrm{ml}$ of SDW under aseptic conditions. After 5-10 minutes, a loopful of sterile water containing of bacterial ooze was streaked separately onto Casamino- acid Peptone Glucose (CPG) agar medium amended with $1 \%$ 2,3,5 triphenyl-tetrazolium chloride (TZC). The plates were incubated at 28 to $30^{\circ} \mathrm{C}$ for $72 \mathrm{hrs}$ and culture morphology was recorded.

To prove infectivity of two representative isolates, pathogenicity test was conducted on 30 days old tomato seedlings (cv. Meghdoot, Syngenta, Pvt. Ltd.) by soil inoculation methods described by Kumar (2006). Briefly, highly virulent colonies from two isolates were separately inoculated into CPG broth and kept in a rotary shaker $(150 \mathrm{rpm})$ for $72 \mathrm{hrs}$. The bacterial suspension containing approximately $1 \times 10^{8} \mathrm{cfu} / \mathrm{ml}$ (absorbance at $600 \mathrm{~nm}=1.0 \mathrm{OD}$ ) was adjusted and poured around the base of collar region of each tomato seedlings ( $20 \mathrm{ml} /$ seedlings). These experimental plants were incubated at 28 to $30^{\circ} \mathrm{C}$ with $12 \mathrm{hrs}$ light/dark photoperiods under glass house conditions. Ten tomato seedlings for each isolates were maintained and similarly seedlings poured with sterile water were served as control. At end of the experiments the days to occurrence of wilt disease and its associated symptoms was recorded.

To identify the races (host specificity) in collected isolates of $R$. solanacearum, the tobacco ( $N$. tabacum L.) seeds were sown and fully expanded leaves from two month old plants were used for the experiment as originally described by (Buddenhagen and Kelman, 1964). Highly fluidal with less-pink centre of single colonies from both the isolates was inoculated separately onto CPG broth and incubated at 28 to $30^{\circ} \mathrm{C}$ with constant agitation $(150 \mathrm{rpm})$. Bacterial cell suspensions from $48 \mathrm{hrs}$ old culture $1 \times 10^{8} \mathrm{cfu} / \mathrm{ml}$ (absorbance at $600 \mathrm{~nm}=1.0$ OD) was prepared and injected carefully on tobacco leaves using sterile hypodermic syringe. Three plants with 8 to 10 infiltrated leaves were maintained as replications for two isolates separately. Leaves infiltrated with 
sterile water were served as control. Plants were regularly watered and maintained under glass house conditions at 25 to $30^{\circ} \mathrm{C}$ for three months with an alternate hrs of light and dark photoperiods. Results were recorded based on the observations made on infiltrated leaves due to the reactions induced by the $R$. solanacearum according to (Lozano and Sequeira, 1970).

\section{Biovar identification and Biolog based finger printing of $\boldsymbol{R}$. solanacearum}

Physiological tests were performed to identify the biovars (biochemically variants) of $R$. solanacearum isolates using the chemical utilization test according to (Hayward, 1964) with slight modifications i.e. use of microfuge tubes instead of conventional test tubes. Briefly, $300 \mu 1$ of Hayward's basal medium was dispensed into each microfuge tubes containing panel of $1 \%(\mathrm{wt} / \mathrm{vol})$ dextrose, lactose, sucrose, maltose, cellobiose (five disaccharides) and mannitol, sorbitol (two sugar alcohols) separately. The bacterial cell suspension $\left(1 \times 10^{8} \mathrm{cfu} / \mathrm{ml}\right)$ was prepared as described above. Then, $50 \mu \mathrm{l}$ of $48 \mathrm{hrs}$ old grown bacterial suspension was dropdown into each microfuge tubes and incubated at 28 to $32^{\circ} \mathrm{C}$ for one week. Hayward's basal medium without carbon sources was served as control. Five replications were maintained for each test for both the isolates and monitored regularly for colour change upto one week. Based on colour changes in Hayward's basal medium the biovar was assigned according to (Hayward, 1964).

Further, the genus and species level identity of two representative isolates was performed through Biolog based phenotypic finger printing assay as per the manufacturer instructions (Biolog Inc., Hayward, CA, GenIII). Biolog is a single panel system which identifies the bacteria upto genus and even species level with pre-selected assay. Bacterial suspension was prepared as per the manufacturer's instruction. Bacterial culture was transferred to reservoir by pipetting $100 \mu \mathrm{l}$ into each of the 96 wells of Biolog microplates containing the 71 carbon sources and 23 chemical sensitivity assays. Test plates were incubated at 28 to $30^{\circ} \mathrm{C}$ for 16 to $24 \mathrm{hrs}$ and then read with existing database using automated plate reader until the genus identity of the test isolate was derived. The Biolog system coupled with sophisticated interpretation software and delivers the result upto species level identity of test bacterium preciously (Albuquerque et al., 2016; Sakthivel et al., 2016).

\section{Results and Discussion}

\section{Phenotypic characterization of $R$. solanacearum}

The characteristics bacterial wilt disease symptoms in tomato samples were recorded collected from Kinathukadavu and Othakalmandapam areas as follows; the first noticeable symptom was drooping of green leaves on young foliage followed by one-side wilt symptoms were recorded. Later, the progression of infection extends water soaked necrotic lesion develops on the aerial shots then the whole plants wilt typically followed plant death was occurred. Cross-section of infected stem was examined and observed brown vascular discolorations in the vascular track. Further, the ooze-out or streaming test shown, the freshly cut end of an infected tomato stem exudes the milky white, slimy ooze from the vascular system into clear water indicated the 'bacterial etiology'. That bacterial ooze into water may appear as "smoky strands or bacterial streaming" contains many bacterial cells, and is a common 'sign' of bacterial wilt disease (Fig. 1a-d). This ooze-out test is a preliminary diagnostic tool for quick and easy detection of $R$. solanacearum in the field and under laboratory conditions. 
Upon isolation, after 48 - $72 \mathrm{hrs}$ of incubation cream coloured, highly fluidal, irregular, opaque single colonies along with pink centre were obtained on $1 \%$ TZC amended CPG media which is typical key characteristics to $R$. solanacearum (Fig. 1e). Two representative isolates collected from Kinathukadavu and Othakalmandapam areas were named as TRsR and TRsP respectively. Pathogenicity test was conducted on 30 days old healthy tomato seedlings (cv. Meghdoot, Syngenta, Pvt. Ltd.). Result revealed, upon soil inoculation the typical bacterial wilt symptoms were recorded within 4 to 5 days post inoculation (dpi). The wilt symptoms characterized as dropping of leaves downwards which further extends to whole branching of plants and finally plant death was occurred as similar to natural field conditions. The disease incidence were recorded at the end of the assay has shown $100 \%$ wilt incidence from both the isolates within 5 - 9 dpi respectively. Further, the exudation of milky white ooze out from cut end of infected stem, and the morphology of the same bacterial culture was re-isolated from artificially infected plants thus fulfilled the Koch's postulate. Plants inoculated with sterile water were remained healthy (Fig. 1f, g).
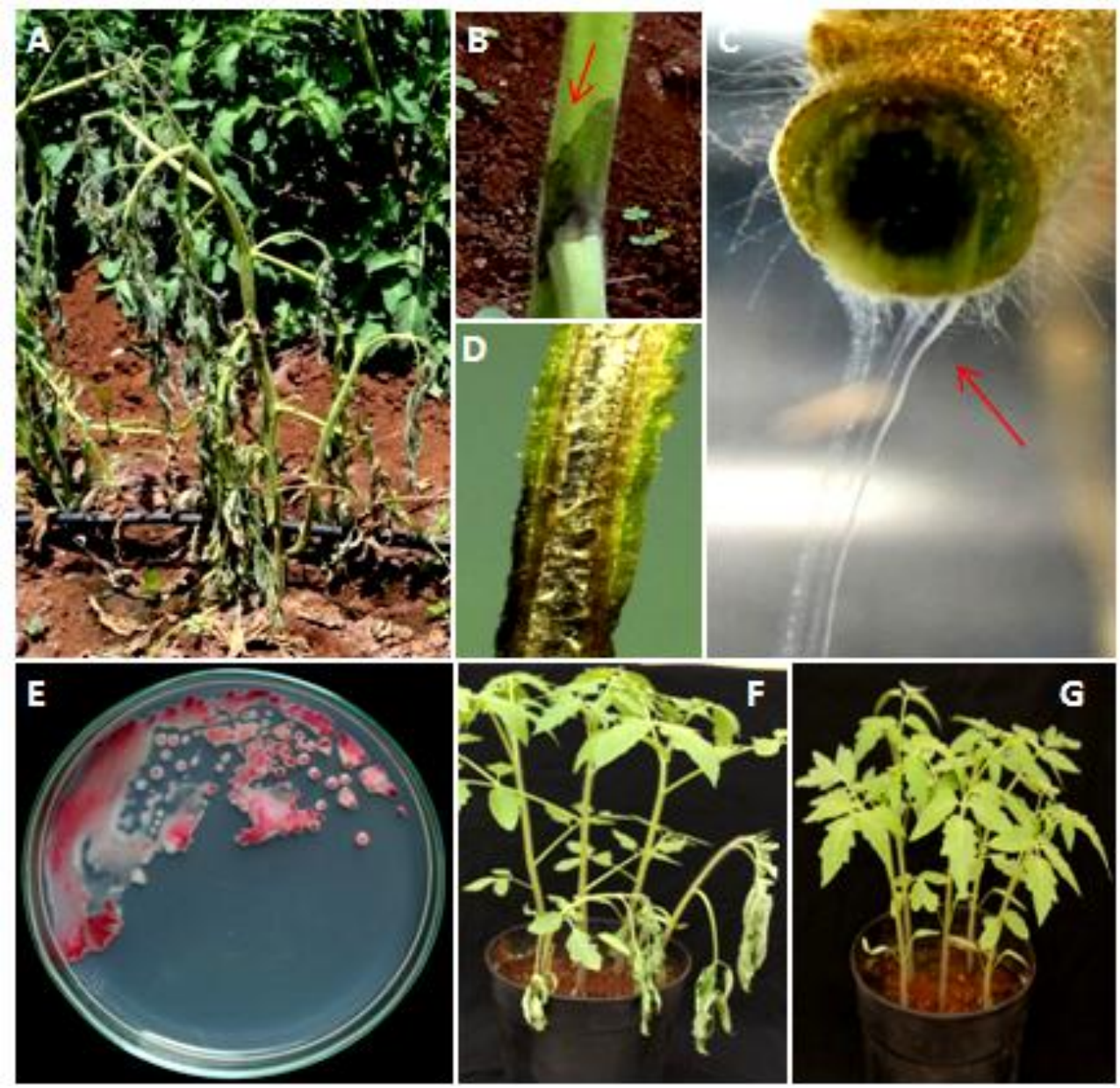

Fig.1 Tomato bacterial wilt symptoms in natural field conditions (A); Water soaked necrotic lesion on aerial shots (B, red arrow); Vascular discolouration (D); Milky white bacterial ooze from the cut end of infected stem confirmed the bacterial etiology (C, red arrow); Culture morphology of $R$. solanacearum on $1 \%$ TZC amended CPG media (E); Typical bacterial wilt symptoms observed in pathogenicity test (F) and plants remained healthy in mock treatment $(\mathrm{G})$. 

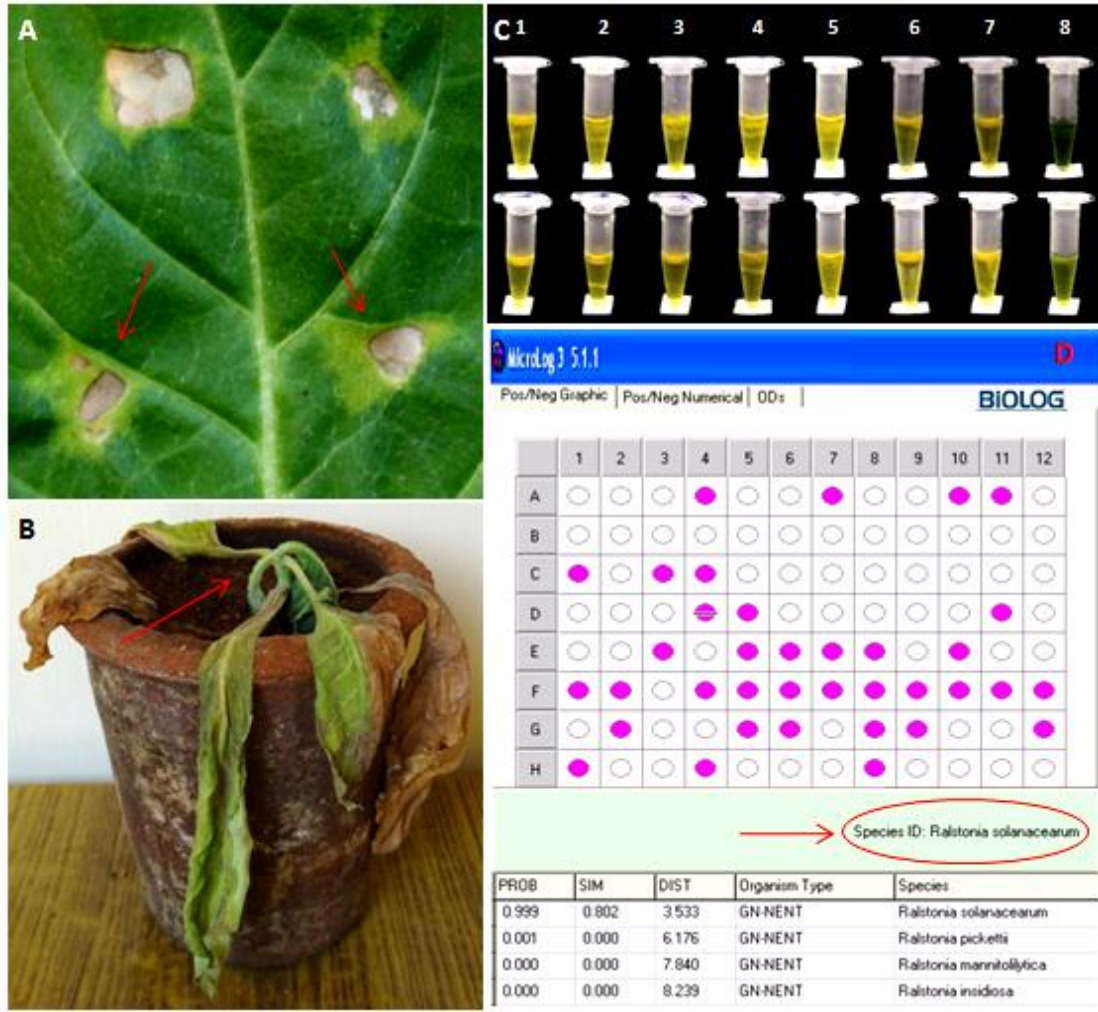

Fig.2 Brown necrotic lesion surrounded by yellow halo (A, red arrow) followed by systemic wilting whole plant (B, red arrow) confirmed its race 1 nature; Disaccharides (1-5, dextrose, lactose, sucrose, maltose, cellobiose) and sugar alcohols (6-7, mannitol, sorbitol) were utilized by TRsR (C, top micorfuge tubes) and TRsP (C, bottom microfuge tubes) isolates showing the colour changes from olive green to yellow that confirmed as biovar 3; No colour changes in the microfuge tubes $(\mathbf{C}, 8)$ served as control. The species level identity for two isolates confirmed as $R$. solanacearum through Biolog based finger printing assay (D, red arrow).

The results obtained in terms of economics Upon tobacco leaf infiltration the brown necrotic reaction was induced on the inoculated spots within $48 \mathrm{hrs}$ of post infiltration. Then initiation of prominent yellow halo was observed surrounding to necrotic reaction and it was increased after 72 hrs of infiltration. Later, the systemic cellular spread of bacteria through vein and veinlets depicted in the size of the necrotic spots along with yellow halo which extends both length and breadth wise followed by extensive wilting of whole plants within a week indicated its host range and which confirmed both isolates of $R$. solanacearum (TRsR and TRP) belong to race 1 . No reaction was induced in leaf infiltrated with sterile water served as control (Fig. 2a, b).

\section{Biochemical characterization of R. solanacearum}

The isolates of $R$. solanacearum were characterized for biovar identity and the results revealed that both the tomato infecting isolates belong to biovar 3 since they changed colour of the medium from olive green to yellow colour containing seven different carbon sources were observed on the microfuge tubes. No colour change was observed in the Hayward's medium which served as control (Fig. 2c). Further the results from Biolog-based phenotypic metabolic finger-printing of two isolates (TRsR and TRsP), which is based on utilization of 71 carbon sources (utilization assays) and 23 chemical sensitivity assays, revealed the 
closest matching similarity with pathogen identity as $R$. solanacearum from the bacterial database collection (Fig. 2d).

$R$. solanacearum were isolated from severe wilt infected tomato plants collected from two different locations of Coimbatore district, Tamil Nadu. The isolates were identified as $R$. solanacearum based on their typical fluidal, irregular culture morphology with a characteristic pink centre on $1 \%$ TZC amended CPG agar medium. Race and biovar test indicated that, both the representative isolates belonged to race 1 and biovar 3 based on tobacco leaf infiltration assay and utilization of different carbohydrate media. Earlier, the prevalence race 1, biovar 3 was also found to be recorded in several parts of mainland's (Kumar et al., 2014; Sagar et al., 2014) as well as from Andaman Islands of India (Sakthivel et al., 2016) in India. Further, the identity of two isolates were confirmed as $R$. solanacearum through Biolog based finger printing assay.

Several phytopathogens can cause wilt diseases in tomato plants including fungal, bacterial, viral, nematode and other abiotic factors. In tomato, four different types of wilt diseases are reported including fusarium wilt (Fusarium oxysporum f. sp. lycopersici); bacterial wilt (Ralstonia solanacearum); sclerotial wilt (Sclerotium rolfsii) and verticilium wilt (Verticillium albo - atrum) respectively. Usually, the external symptoms alone are difficult to identify these wilt diseases accurately and little confusable. However, many specific diagnostic characters of the disease provide the fundamentals knowledge to rule out the exact cause the disease (Denny, 2007). The field diagnostic test called 'streaming or ooze-out test' can ruled out the specific and accurate detection of bacterial wilt infection tomato, however other fungal wilt inciting agents do not produce such ooze in the water container.
The outcome of this study confirmed the prevalence of bacterial wilt disease of tomato incited by race 1 , biovar 3 of $R$. solanacearum in Coimbatore district of Tamil Nadu. Representative isolates highly virulent on tomato as well as tobacco led to death of plants were recorded. However, among all other races the $R$. solanacearum strains belong to race 1 , biovar 3 is considered as most economically important disease in solanaceaous crops worldwide as well as from India which reported to cause wilt disease in tomato, eggplant, chilli, potato and tobacco respectively (Denny, 2006; Kumar et al., 2014; Garcia et al., 2019). This research findings forewarning the future spread of the $R$. solanacearum strains within Tamil Nadu state particularly for solanaceous vegetables cultivation. Therefore, implement of effective disease management strategies with suitable formulation is utmost important before its severe spread to other locations.

\section{Acknowledgements}

We thank University Grants Commission (UGC) for providing financial assistance to carry out this study. Various facilities provided by the Head of the department, Department of Plant Pathology, Tamil Nadu Agricultural University, Coimbatore, are gratefully acknowledged. Also, we gratefully thankful to Dr. K. Sakthivel, Scientist, ICARIIOR, Hyderabad and Dr. A. Kumar, Principal Scientist, ICAR-IARI, New Delhi for their valuable guidance to completion of this works successfully.

\section{References}

Albuquerque, M.R., M.F. Silva, J.R. Silva, E.B. Souza, A.S. Gama and Mariano, L.R. 2016. First Report of Bacterial Wilt Caused by Ralstonia pseudosolanacearum on Eruca vesicaria subsp. sativa in Brazil. Plant Disease. 100 (11):2319-2319.

Buddenhagen, I., and Kelman, A. 1964. 
Biological and physiological aspects of bacterial wilt caused by Pseudomonas solanacearum. Annual Review of Phytopathology. 2 (1): 203-230.

Denny, T., 2007. Plant Pathogenic Ralstonia Species. In Plant-Associated Bacteria. 573644. Springer.

Fegan, M., and Prior, P. 2005. How complex is the Ralstonia solanacearum species complex. Bacterial wilt disease and the Ralstonia solanacearum species complex. Edited by C. Allen, P. Prior and A.C. Hayward. Minnesota, APS Press. 1: 449461.

Garcia, R.O., J.P. Kerns and Thiessen, L. 2019. Ralstonia solanacearum Species Complex: A Quick Diagnostic Guide. Plant Health Progress. 20 (1):7-13.

Hayward, A.C, 1964. Characteristics of Pseudomonas solanacearum. Journal of Applied Bacteriology. 27 (2):265-277.

Kumar, A., 2006. Methods for screening ginger (Zingiber officinale Rosc.) for bacterial wilt resistance. Indian Phytopathology. 59 (3):281-286.

Kumar, A., T.P. Prameela, R. Suseelabhai, A. Siljo, M. Anandaraj and Vinatzer, B.A. 2014. Host specificity and genetic diversity of race 4 strains of Ralstonia solanacearum. Plant Pathology. 63 (5):1138-1148.

Lozano, J.C., and Sequeira, L. 1970. Differentiation of races of Pseudomonas solanacearum by a leaf infiltration technique. Phytopathology. 60:833-838.

Mansfield, J., S. Genin, S. Magori, V. Citovsky, M. Sriariyanum, P. Ronald, M.A.X. Dow, V. Verdier, S.V. Beer and Machado, M.A. 2012. Top 10 plant pathogenic bacteria in molecular plant pathology. Molecular Plant Pathology. 13 (6):614-629.

Ram, D., C. Satish and Ngachan, S.V. 2013. Evaluation of tomato genotypes against bacterial wilt (Ralstonia solanacearum) under mid-hill conditions. Indian Phytopathology. 66 (1):96-97.

Rocha, M.D.C., R. Deliza, F.M. Correa, M.G.F. do Carmo and Abboud, A.C.S. 2013. A study to guide breeding of new cultivars of organic cherry tomato following a consumer-driven approach. Food Research International. 51 (1):265-273.

Sagar, V., A. Jeevalatha, S. Mian, S.K. Chakrabarti, M.S. Gurjar, R.K. Arora, S. Sharma, R.R. Bakade and Singh, B.P. 2014. Potato bacterial wilt in India caused by strains of phylotype I, II and IV of Ralstonia solanacearum. European Journal of Plant Pathology. 138 (1):51-65.

Sakthivel, K., R.K. Gautam, K. Kumar, S. Dam Roy, A. Kumar, C. Devendrakumar, M. Vibhuti, S. Neelam and Vinatzer, B.A. 2016. Diversity of Ralstonia solanacearum strains on the Andaman Islands in India. Plant Disease. 100 (4):732-738.

Smith, E.F., 1896. A bacterial disease of the tomato, eggplant and Irish potato. US Dept. Agric. Div. Veg. Phys. Path. Bull. 12:1-26.

Yabuuchi, E., Y. Kosako, I. Yano, H. Hotta and Nishiuchi, Y. 1995. Transfer of Two Burkholderia and An Alcaligenes Species to Ralstonia Gen. Nov. Proposal of Ralstonia pickettii (Ralston, Palleroni and Doudoroff 1973) Comb. Nov., Ralstonia solanacearum (Smith 1896) Comb. Nov. and Ralstonia eutropha (Davis 1969) Comb. Nov. Microbiology and Immunology. 39 (11):897-904.

\section{How to cite this article:}

Balamurugan, A., M. Muthamilan, A. Kamalakannan, A. Shanthi and Arumugam, T. 2020. Characterization of Ralstonia solanacearum Causing Bacterial Wilt Disease of Tomato in Coimbatore District of Tamil Nadu, India Int.J.Curr.Microbiol.App.Sci. 9(02): 3010-3016. doi: https://doi.org/10.20546/ijcmas.2020.902.345 